\section{The misues of knoweledge: bioethics and security issues related to synthetic biology}

Tatjana Marinkovic ${ }^{1}$, Veljko Samardzic ${ }^{2}$, Aleksandar Pajic ${ }^{3}$, Dragan Marinkovic ${ }^{4}$

${ }^{1}$ High School of Professional Studies, Uzice, Serbia

${ }^{2}$ Higher Vocational School for Entrepreneurship, Belgrade, Serbia 3VSZSS "Visan"

Belgrade, Serbia

${ }^{4}$ University of Belgrade, Faculty of Special Education and

Rehabilitation, Belgrade, Serbia

\section{Abstract}

The design and construction of new biological systems in the way engineers design electronic or mechanical systems is the primary goal of synthetic biology. The ability to create and modify life forms and easy access to information to do so has raised a number of issues related to ethics and security. In the era of rapid development of biotechnology, and the perception of the consequent risks to the environment and health, the ethics of knowledge becomes a matter of practical significance. The concern about the misuse of knowledge from synthetic biology influences new risk reduction strategies, which can have significant effects on scientific progress. This paper will provide an overview of the main bioethical and biosafety issues of synthetic biology.

Ključne reči: Synthetic biology, bioethics, biosecurity, censorship, environmental risk, health risk

\section{Zloupotreba znanja: Bioetička i bezbednosna pitanja vezana za sintetičku biologiju}

\author{
Tatjana Marinković ${ }^{1}$, Veljko Sanmardžić ${ }^{2}$, Aleksandar Pajić3 \\ Dragan Marinković ${ }^{4}$ \\ ${ }^{1}$ Visoka škola strukovnih studija Užice, Užice, Srbija \\ ${ }^{2}$ Visoka strukovna škola za preduzetništvo, Beograd, Srbija \\ ${ }^{3}$ Visoka zdravstveno-sanitarna škola strukovnih studija ,Visan“, \\ Beograd, Srbija \\ ${ }^{4}$ Univerzitet u Beogradu, Fakultet za specijalnu edukaciju i \\ rehabilitaciju, Beograd, Srbija
}

\section{Apstrakt}

Projektovanje i izgradnja novih bioloških sistema na način kako inženjeri dizajniraju elektronske ili mehaničke sisteme je primaran cilj sintetičke biologije. Sposobnost stvaranja i modifikacije životnih oblika i lak pristup informacijama kako to učiniti, pokrenula je brojna pitanja vezana za etiku i bezbednost. U doba brzog razvoja biotehnologije, i uviđanja posledičnih rizika po životnu sredinu $i$ zdravlje, etika znanja postaje stvar od praktičnog značaja. Zabrinutost zbog zloupotrebe znanja iz sintetičke biologije utiče na nove strategije za smanjenje rizika, a što može imati značajne efekte na naučni napredak. Ovaj rad će dati pregled glavnih bioetičkih i biosigurnosnih pitanja sintetičke biologije.

Key words: Sintetička biologija, bioetika, biosigurnost, cenzura, rizik životne sredine, zdravstveni rizik.

\title{
Introduction
}

Synthetic biology is an emerging discipline based on the use of computer-assisted, engineering principles to design and construct new synthetic biological parts, devices and systems that do not exist in nature and the redesign of existing biological organisms ${ }^{1,2}$.

Barbara Hobom used the name "synthetic biology" for the first time in 1980, to describe bacteria that had been genetically engineered using recombinant DNA technology ${ }^{3}$. These bacteria are living systems (therefore biological) that have been altered by human intervention (synthetically). In this respect, synthetic biology was largely synonymous with "bioengineering", as introduced a decade ago ${ }^{4}$. However, in 2000, the term "synthetic biology" was reintroduced by Eric Kool to describe the synthesis of unnatural organic molecules that function in living systems ${ }^{5}$. Basically, although there are similarities with recombinant DNA technology and genetic engineering, the main difference is that synthetic biology introduces synthetically constructed parts and is not limited to the modification of natural organisms ${ }^{1,2}$.

The definition of synthetic biology is also debated in the human sciences, arts and politics. One popular definition is that synthetic biology represent "designing and constructing of biological modules, biological systems, and biological machines or, re-design of existing biological systems for useful purposes"2. 
At the most basic level, synthetic biology involves the use synthetic DNA that was uploaded or written on a computer and "printed" out from bottles of nucleic acids (adenine, thymine, cytosine, and guanine, represented by the letters A, T, C, and G). These DNA strands are then inserted into organisms through a variety of genetic engineering techniques ${ }^{6}$.

The emergence and rapid development of synthetic biology rely on three key technological enablers:

- Computational modeling

- DNA sequencing

- DNA synthesis

In other word, synthetic biology requires ability to perform a modeling of the design and to predict system performance prior to fabrication. Clearly, efficient DNA sequencing, or reading DNA, is necessary for this kind of modeling. Once a genome has been sequenced, the next step may be to "re-write", or synthesize, all or part of the genome.

Discussing the new possibilities of modeling in synthetic biology, Drew Endy from MIT said, "Biological engineers of the future will start with their laptops, not in the laboratory." Just to recall, while computers store and process information in binary strings - coded as the numbers 0 and 1 - DNA operates in (mathematical) base four. Its information is coded by the sequence of the four nucleotide bases, A, C, T and G. The bases are spaced every $0.35 \mathrm{~nm}$ along the DNA molecule, giving DNA a data density of over one-half million gigabits per square centimeter, many thousands of times denser than a typical hard drive ${ }^{7}$.

At the beginning, the aim of synthetic biology was to create a range of standardized biological parts, so called BioBricks, to produce customized biological systems. MIT has built a registry of over 20000 such modules, which are available as an open source resource. BioBricks are used to design and assemble larger synthetic biological circuits from individual parts and combinations of parts with defined functions, which would then be incorporated into living cells such as Escherichia coli cells to construct new biological systems. The application for BioBricks are numerous. They are including bioremediation, where microorganisms or even plants could be engineered to degrade pesticides and remove pollutants or formation of biosensors 8,9 .

There is a range of potential applications of synthetic biology in medicine. For example, regulatory circuits could be designed which trigger insulin production in diabetes. Bacteria or viruses could be programmed to identify malignant cancer cells and deliver therapeutic agents. Viruses have also been engineered to interact with HIV-infected cells, which could prevent the development of AIDS (reviewed in ${ }^{1}$ ).

One of the most widely discussed areas of future application of synthetic biology research is biofuels. There are many ways of engineering microorganisms to produce carbon-neutral (or more environmentally friendly) sources of energy. For example, bacteria could be engineered to synthesize hydrogen or ethanol by degrading cellulose, although further work is needed to overcome technical barriers ${ }^{2}$.

The main question regarding synthetic biology is if it would be possible to create a life out of non-living elements. DNA synthesis was introduced several decades ago. However, the increasing speed and decreasing cost of DNA synthesis will assist the progress of experimental research in the biological sciences. While synthesis of first gene took several years to be performed, nowadays an advance in DNA synthesis technology enabled rapid synthesis of whole genome. Thus, already in 2002. Eckard Wimmer's group reported the synthesis of the poliovirus genome ${ }^{10}$ - In 2010. Craig Venter's group published the creation of the first living and replicating bacterium with a synthetic genome ${ }^{11}$. As Venters' group published in Science journal, the complete synthetic M. mycoides genome was isolated from the yeast cell and transplanted into Mycoplasma capricolum recipient cells that have had the genes for its restriction enzyme removed. The synthetic genome DNA was transcribed into messenger RNA, which in turn was translated into new proteins. The M. capricolum genome was either destroyed by M. mycoides restriction enzymes or was lost during cell replication. After two days viable $M$. mycoides cells, which contained only synthetic DNA, were clearly visible on petri dishes containing bacterial growth medium ${ }^{12}$. 


\section{Ethical issues of syntetic biology}

Clearly, the formation of living cell raised numerous ethical and social issues. Obviously, some of the most impactful applications of synthetic biology could yield massive benefits to human health, the environment and various industries. However, synthetic biology's critics argue that the rising field will create a world of unnatural, harmful organisms. There is an evident worry that in the case that synthetic life is released into the environment, the ecosystem could face adverse consequences.

In 2010. Thomas Douglas and Julian Savulescu wrote an extensive review of ethical issues of synthetic biology ${ }^{2}$, starting with description of one possible scenario:

"It's 2020. Designer viruses are now used to treat some cancers and infectious diseases. But they're expensive and difficult to manufacture. An old college friend of yours, an eminent synthetic biologist, calls you for advice. She's discovered a new, cheap way to produce synthetic viruses using outof-date bench top DNA synthesisers that are now ubiquitous, even in developing countries. She's excited about the discovery and is hoping to publish it in Nature. She thinks it could bring a wide range of medical treatments, not to mention research tools, within the grasp of the developing world. There's just one catch. Every major military and terrorist group in the world has access to these obsolete synthesisers. It would take only one malevolent agent and one such machine to produce enough vaccine-resistant smallpox virions to devastate humanity."

Douglas and Savulescu recognized tree major concerns regarding synthetic biology. First, it is "playing God". For thousands of years, science and religion have clashed, and the notion of "playing God" seems to be the basis for objection each time. Nearly every biotechnological accomplishment - anesthesia, birth control, stem cell research, genetic engineering and now synthetic biology-has been met with objections and charges that scientists have violated the natural order of life. Synthetic biology is giving us an opportunity to perform genetic make-up of future beings within the restriction of timescales and genetic possibilities dictated by evolution.

The widely discussed concern about genetic modification was that genetic engineering is usurpation of the role of a higher being or failing to recognize human limitations ${ }^{13}$. Now, with ability to design and perform the de novo creation of life, the accusation of scientists "playing God" is even more dramatic.

Second interesting ethical concern about synthetic biology is that it may result in the creation of entities which fall somewhere between living things and machines ${ }^{2}$. The bacterial bio-factories, constructed by addition of suitable modules to a minimal bacterial chassis, possess many of the characteristics of life: homeostatic physiological mechanisms, a nucleic acid genome and protein-based structure, and the ability to reproduce. On the other hand, they possess many of the features characteristic of machines: for example, modular construction based on rational design principles, with specific applications in mind. Mildred Cho and collaborators ${ }^{7}$ expressed concern that this may develop an attitude that life is nothing more than a set of biochemical components, or, more restrictively, a set of genes. This, in turn, will undermine "the special status of living things and the value that we ascribe to life", particularly the moral status of living. However, we already do not assign any particular moral status to living organisms such are viruses and bacteria. Obviously, there is already an uncertainty in our assignments of moral status. While we can be confident that persons have significant moral status, and machines do not, there is plenty of grey area in between and it seems plausible that many synthetic entities would fall within this grey area ${ }^{13}$.

As a third important ethical issue concerning synthetic biology, Douglas and Savulescu are discussing the misuse of knowledge. Although this concern is repeatedly raised upon almost every achievement of biotechnology, de novo synthesis of human pathogens - the poliovirus, and the 1918 Spanish influenza virus drowned a particular attention regarding misuse of knowledge. 


\section{The misuse of knowledge}

In the era of rapid biotechnology advance, the ethics of knowledge become a matter of practical importance, as there are serious recognized environmental and health risks. Thus, concerns about misuse of knowledge from synthetic biology are influencing new risk reduction strategies that could have substantial effects on scientific progress. On the other hand, ethicists are well placed to contribute positively to the selection of appropriate strategies.

Risk reduction strategies include three broad approaches, as Douglas and Savulescu are describing:

1. A laissez faire approach — scientists and their institutions are left to deal with (or ignore) the concerns about misuse as they see fit.

2. A requirement for consideration-scientists and/or their institutions are required to assess the risk of misuse posed by their work, but are left free to respond as they see fit.

3. A requirement for independent consideration - certain projects/findings must be considered by an independent body before being funded, undertaken, or published.

A particular concern was raised upon above mentioned de novo production of polio and Spanish influenza viruses ${ }^{10,14}$. Very recently, Noyce at al. published a paper describing construction of an infectious horsepox virus vaccine from chemically synthesized DNA fragments ${ }^{15}$. Since horsepox is a close relative to smallpox virus, this publication again raised concern that this may present a step-by-step manual how to make a biological weapon ${ }^{16}$.

Let's remind that smallpox is on categorized in A category of bioterrorism agents/disease by Centers for Disease Control and Prevention (CDC).

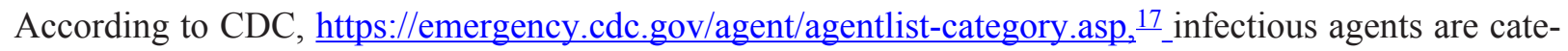
gorized as bioterrorist agents as follows:

\section{Bioioterrorism agents/disease}

\section{Category A}

Definition

The U.S. public health system and primary healthcare providers must be prepared to address various biological agents, including pathogens that are rarely seen in the United States. High-priority agents include organisms that pose a risk to national security because they

- can be easily disseminated or transmitted from person to person;

- result in high mortality rates and have the potential for major public health impact;

- might cause public panic and social disruption; and

- require special action for public health preparedness.

Agents/Diseases

- Anthrax (Bacillus anthracis)

- Botulism (Clostridium botulinum toxin)

- Plague (Yersinia pestis)

- Smallpox (variola major)

- Tularemia (Francisella tularensis)

- Viral hemorrhagic fevers, including

- Filoviruses (Ebola, Marburg)

- Arenaviruses (Lassa, Machupo) 


\section{Category B}

\section{Definition}

Second highest priority agents include those that

- are moderately easy to disseminate;

- result in moderate morbidity rates and low mortality rates; and

- require specific enhancements of CDC's diagnostic capacity and enhanced disease surveillance.

Agents/Diseases

- Brucellosis (Brucella species)

- Epsilon toxin of Clostridium perfringens

- Food safety threats (Salmonella species, Escherichia coli O157:H7, Shigella)

- Glanders (Burkholderia mallei)

- Melioidosis (Burkholderia pseudomallei)

- Psittacosis (Chlamydia psittaci)

- Q fever (Coxiella burnetii)

- Ricin toxin from Ricinus communis (castor beans)

- Staphylococcal enterotoxin B

- Typhus fever (Rickettsia prowazekii)

- Viral encephalitis (alphaviruses, such as eastern equine encephalitis, Venezuelan equine encephalitis, and western equine encephalitis])

- Water safety threats (Vibrio cholerae, Cryptosporidium parvum)

\section{Category C}

Definition

Third highest priority agents include emerging pathogens that could be engineered for mass dissemination in the future because of

- availability;

- ease of production and dissemination; and

- potential for high morbidity and mortality rates and major health impact.

Agents

Emerging infectious diseases such as Nipah virus and hantavirus

Therefore, the major biosafety risk of synthetic biology, the accidental release of synthetic organisms, which could have unintended detrimental effects on the environment or on human health, now it is getting overcome by the risk of intentional misuse of scientific data.

\section{Publication of sensitive data}

Following publication of papers that described how to synthesize the mousepox and polio genomes, many concern grew about the risk of physical harm following publication, when the information was accessible.

In 2004. USA established National Science Advisory Board for Biosecurity (NSABB). One of the issues on which the NSABB advises government and researchers is the communication of the results of what the Board calls "dual-use research of concern." According to the National Institutes of Health, Dual Use Research of Concern is "life sciences research that can be anticipated to provide knowledge, information, products, or technologies that could be directly misapplied to pose a significant threat with potential consequences to public and environmental health and safety" 18 
Although a number of scientists have argued that some knowledge learned from synthetic biology should be kept secret, the pressure to keep data secret could be considered as censorship. From this point of view, numerous arguments against censorship were raised. One group is arguing that, as a matter of principle, censorship is unethical. Some of the critics of the censorship are considering it unrealistic and impractical, arguing that it is simply impossible to keep knowledge secret ${ }^{19,20}$.

On the other hands, there are arguments that censorship will prevent development of antidotes and other strategies for managing dangerous substances. If there were to be a discovery, say a synthetic polio virus was created, does the public have the right to know in order to stay "safe'?

In most cases where scientific knowledge can be misused there are strategies available for minimizing the risk of misuse once the knowledge has been created and disseminated. In 2006, a Guardian journalist ordered a segment of the smallpox virus genome and succeeded in having it delivered to his home address; perhaps better regulation of DNA sales or benchtop DNA synthesisers could prevent the distribution of such sequences. At a state level, strong enforcement of the biological and chemical weapons conventions could mitigate risks of misuse.

\section{Conclusion}

With regards to the field of synthetic biology, it is currently probably impractical to make every discovery known to the public, due to the speculation, and scrutiny that may be received from those who are uneducated about the relatively new field. But the question is, should the pioneers of synthetic biology do more to educate the public, or would it be more beneficial to censor some discoveries?

\section{References}

1. Bartley BA, Kim K, Medley JK, Sauro HM. Synthetic Biology: Engineering Living Systems from Biophysical Principles. Biophys J. 2017 Mar 28;112(6):1050-1058. doi: 10.1016/j.bpj.2017.02.013.

2. Douglas T, Savulescu J. Synthetic biology and the ethics of knowledge.J Med Ethics. 2010 November ; 36(11): $687-$ 693. doi:10.1136/jme.2010.038232.

3. Hobom B Gene surgery: on the threshold of synthetic biology].Med Klin. 1980 Nov 21;75(24):834-41. German

4. Agarwal KL, Büchi H, Caruthers MH, et al. Total synthesis of the gene for an alanine transfer ribonucleic acid from yeast. Nature. 1970; 227:27-34. [PubMed: 5422620]

5. Ohmichi T, Kool ET. The virtues of self-binding: high sequence specificity for RNA cleavage by self-processed hammerhead ribozymes.Nucleic Acids Res. 2000 Feb 1;28(3):776-83.

6. Parliamentary Office of Science and Technology. The dual-use dilemma. Parliamentary Office of Science and Technology; London: 2009.

7. Cho MK, Magnus D, Caplan AL, et al. Ethical considerations in synthesizing a minimal genome. Science. 1999; 286:2087-9. [PubMed: 10617419]

8. https://biobricks.org/

9. Shetty, Reshma P.; Endy, Drew; Knight, Thomas F. (2008-04-14). "Engineering BioBrick vectors from BioBrick parts”. Journal of Biological Engineering. 2 (1):5. doi:10.1186/1754-1611-2-5. ISSN 1754 1611. PMC 2373286. PMID 18410688.

10. Cello J, Paul AV, Wimmer E. Chemical synthesis of poliovirus cDNA: generation of infectious virus in the absence of natural template. Science. 2002; 297:1016-18. [PubMed: 12114528]

11. Gibson DG, Glass JI, Lartigue C, et al. Creation of a Bacterial cell controlled by a chemically synthesized genome. Science. 2010; 329:52-6. [PubMed: 20488990]

12. Gibson DG, Benders GA, Andrews-Pfannkoch C, et al. Complete chemical synthesis, assembly, and cloning of a Mycoplasma genitalium genome. Science. 2008; 319:1215-20. [PubMed: 18218864]

13. Buchanan A. Moral status and human enhancement. Philos Public Aff. 2009; 37:346-81

14. Tumpey TM, Basler CF, Aguilar PV, et al. Characterization of the reconstructed 1918 Spanish Influenza pandemic virus. Science. 2005; 310:77-80. [PubMed: 16210530]

15. Noyce RS, Lederman S, Evans DH.Construction of an infectious horsepox virus vaccine from chemically synthesized DNA fragments. PLoS One. 2018 Jan 19;13(1):e0188453. doi: 10.1371/journal.pone.0188453. eCollection 2018.

MATERIA MEDICA • Vol. $34 \cdot$ No. $2 \cdot$ maj 2018. 
16. Noyce RS, Evans DH. Synthetic horsepox viruses and the continuing debate about dual use research. PLoS Pathog. 2018 Oct 4;14(10):e1007025. doi: 10.1371/journal.ppat.1007025. eCollection 2018 Oct.

17. https://emergency.cdc.gov/agent/agentlist-category.asp

18. Parliamentary Office of Science and Technology. The dual-use dilemma. Parliamentary Office of Science and Technology; London: 2009.

19. National Research Council. Biotechnology research in an age of terrorism. National Research Council of the National Academies, The National Academies Press; Washington, DC: 2004.

20. Selgelid MJ. A tale of two studies: ethics, bioterrorism, and the censorship of science. Hastings Cent Rep. 2007; 37:35-43. [PubMed: 17649901] 